\title{
Return of beverage and food companies in Indonesia and its factors
}

Dirvi Surya Abbas ${ }^{1}$, Imam Hidayat ${ }^{2}$

Universitas Muhammadiyah Tangerang ${ }^{1,2}$

abbas.dirvi@gmail.com

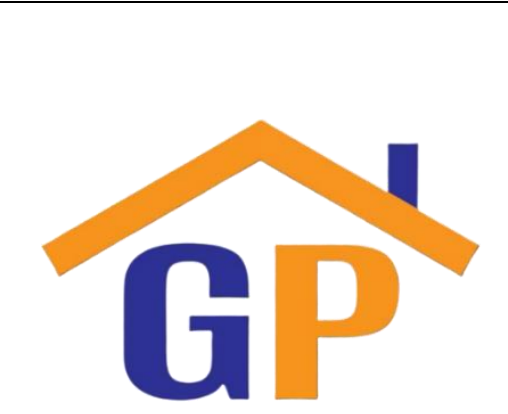

Article History

Received on 30 November 2020

Revised on 8 January 2021

Accepted on 21 January 2021

\begin{abstract}
Purpose: This study aimed to determine the impact on stock returns of food and beverage companies in Indonesia during the period 2013-2018 of instrument finance and systemic risk.

Methodology: The sampling technique used purposive sampling. Based on the predetermined criteria, eight companies. Data used secondary data obtained from IDX. The method used is regression analysis logistic panel data.
\end{abstract}

Results: Return on equity \& systematic risk affected stock returns. Price earning ratio \& debt to equity ratio did not affect stock returns.

Limitation: The data used is only for food and beverage companies and does not include manufacturing companies as a whole.

Contribution: Investors are expected to analyze the company's condition that will invest their capital; besides using technical analysis, it is also better to use fundamental analysis.

Keywords: Instrument finance, Systematic risk, Return

How to cite: Abbas, D. S., \& Hidayat, I. (2020) Return of beverage and food companies in Indonesia and its factors. Journal of Sustainable Tourism and Entrepreneurship, 1(3), 245-254.

\section{Introduction}

Consumer goods company is one of the industrial sectors which is engaged in basic human needs. Because it is involved in a strategic field, many new consumer goods companies have emerged in Indonesia, which has sharpened competition in this industry. One of the most desirable sub-sectors is food and beverages companies. Food and beverage companies are one of the sub-sector companies classified as stable and tends not to be quickly affected by seasons and economic conditions. Food and beverage companies play an essential role in fulfilling consumer needs; people's needs for food and beverage products will always exist because they are among the basic needs of human life. Based on this fact, food and beverage companies are considered to be sustainable.

The development of food and beverage companies has the opportunity to grow and develop; this is evidenced by the increasing number of food and beverage companies listed on the Indonesia Stock Exchange (IDX). According to IDX records until August 2017 food and beverages companies listed 16 companies. The existence of the Indonesia Stock Exchange further supports industrial growth in the food and beverage sector. However, there may be a decline in growth at certain times. Evidenced by the occurrence of several companies that have decreased stock returns. The following is a table of stock returns from several companies included in the food and beverages subsector: 


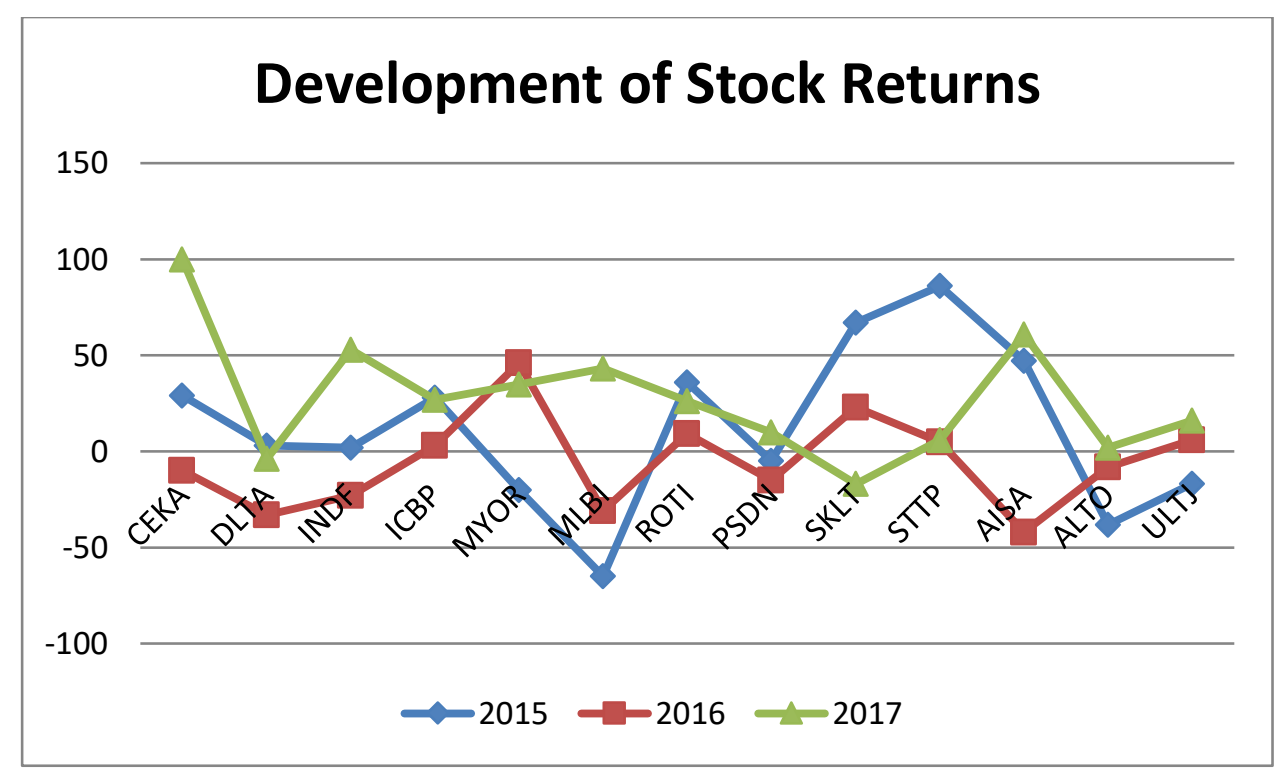

Figure 1. Stock Returns companies Food and Beverages in Indonesia (2014-2016) Source: Processed Data (2019)

Based on figure 1.1, it can be seen that PT Indofood Sukses Makmur Tbk experienced a decline in stock returns by $25 \%$ in 2015 , although it had experienced a decline, in 2016, it managed to rise and rose to reach $53 \%$. The same is the case with PT Siantar TOP Tbk. with a stock return in 2015 of $5 \%$, a decrease from the previous year with a difference of $81 \%$. From 2014 to 2016, there was an increase or decrease in stock returns during the analysis period. The table also shows that there is still the lowest return that is negative throughout the analysis period. There is no certainty regarding investors' return when investing in stocks, so investors need rational considerations by gathering various types of information required for making investment decisions.

A rational investor will consider two things, namely the expected return and the risk contained in the alternative investment made. Stock return is the level of return enjoyed by investors on an investment they make. The return component consists of two types, namely current returns and capital gains. Current income is the profit earned through periodic payments such as deposit interest, bond interest, dividend, etc. The second part of the return is capital gain, which is the profit earned on account of the price difference between the purchasing price and the sale price of the stock sold on the capital market. The selling and acquisition would result in a shift in the share price in the form of capital gains (Suherman \& Siburian, 2013). Every investor certainly desires to get a high return. Still, the desire to get a high stock return also has a high risk and uncertainty in determining stock returns, making it difficult for investors to predict. The delay in resolving the stock return is influenced by fluctuations in stock prices that rapidly rise and fall.

Based on the background of the problems above, the following results of problem identification in this study are as follows:

a. Price Earning Ratio (PER) can affect stock returns. The higher this ratio indicates that investors have reasonable expectations about its future development. However, in the company's current condition, PER has limitations, namely when the company experiences negative profit (loss), PER will not be meaningful, and changes in earnings also cause PER to change drastically.

b. A low Return on Equity (ROE) value indicates or describes the company's condition as not doing well. This will impact decreasing the rate of return desired by shareholders, so to fulfill the wishes of shareholders, the company must make a return on capital according to maturity so that the resulting ROE value is not low.

c. Debt to Equity Ratio (DER) is the ratio between the debt owed by a company and total equity. DER reflects the company's ability to fulfill all of its obligations, indicated by some of its capital used to pay debts. This ratio compares a loan or debt funds and prosperity in the company's development efforts. Suppose the company's Debt to Equity Ratio (DER) is high. In that case, 
there is a possibility that the company's stock price will be low because if the company makes a profit, the company tends to use that profit to pay its debts compared to dividing dividends.

d. Risk is a deviation in cash flow that may occur in the future. Systematic risk is often referred to as market risk, general risk, systematic risk, or known risk. Rare chances are generally frequent and brutal to avoid. If a systematic risk arises and occurs, all types of shares will be affected so that investment in one or more shares cannot reduce losses. In general, investors tend to avoid risk, so if an investor is dealing with high-risk investment activities, he will surely expect to get a high return rate (return) from these securities.

e. Return on Assets (ROA), which is a measure of the company's effectiveness in generating profits (return) by utilizing assets owned by the company. the higher the ROA value, the company's performance is considered to be better and vice versa. ROA has a relationship with the rate of return (return) from investment activities. Increasing ROA shows that the company is considered capable of producing high corporate profits and impacting its stock price increases. This affects increasing share prices and also increases the company's stock returns.

\section{Literature review and hypotheses development}

The theory of the signal suggests how an organization can provide financial statement users with signals. This signal is in the form of data on what management has done in order to fully understand the desires of the owner. This information may be provided voluntarily by the management of the organization in financial reports, company policy information, or other information. Signals may be in the form of discounts or extra data showing that the business is better than other businesses (Meythi and Hartono, 2012). In this case, information relating to stock returns is given by the firm, such as financial results in the form of cash flows, income and book value.

When the information is announced, investor responses are reflected by shifts in share prices. The word was given to all market players; market players first perceive and evaluate it as a good signal (good news) or a wrong direction (bad news). If the investor sees the announcement of this information as a positive indicator, the stock price will change; The share price would rise in order to increase the return on the stock.

The authors infer from the three concepts above that the details published as an announcement would indicate investors. If the statement contains a positive value, it is assumed that when the market receives the notification, the market will respond. When the data is released and all industry participants have obtained the data, It will first be perceived and evaluated by market participants as a positive signal (good news) or a wrong signal (bad news). If the disclosure of this information is a good signal to investors, the trading volume of shares will change; if it is a lousy signal, investors will withhold the company's investment.

\subsection{Price earning ratio and stock return}

The higher the PER of stock, the higher the share price to buy, the better the performance per share to attract investors to buy the stock. PER that is too high identifies that its stock market price is already high (Murhadi, 2013). The price earning ratio is one of the investors' rates to show a company's profitability to return funds at a certain share price level. The higher the PER value, the higher the investor's interest in investing in the company.

According to Absari \& Chandrarin (2012), PER does not affect stock returns. These studies' results have the same results as research conducted by Haruman (2005), proving that PER has no impact on stock returns. In contrast to the research results achieved by Rahyuda \& Puspitadewi (2016), PER has a positive and significant effect on Stock Returns. Based on the description above, the hypothesis put forward is as follows:

H1: Price Earning Ratio affects Stock Returns

\subsection{Return on equity and stock return}

$\mathrm{ROE}$ is one of the profitability ratios that describe the company's ability to generate a return or profit on the capital that has been invested by the investor. The greater the ROE value, the better the company is, according to investors. 
In research conducted by Budialim (2013) and Pinatih \& Lestari (2017), it is stated that ROE has a positive effect on Stock Returns. This is because the higher the net profit after tax, the higher the ROE value. A high ROE value results in increased stock prices and returns.

However, according to research conducted by Absari and Susilowati, and Turyanto (2011), ROE does not affect stock returns. This result contradicts the theory that Return on Equity is a measure of profitability, where shareholders generally want to know the probability level of share capital and the profits they have planted back in the form of invested profits. If the company's shares are traded on the stock exchange, the Return on Equity level will affect the level of demand for these shares on the stock exchange and the selling price. Based on the description above, the hypothesis put forward is as follows:

H2: Return on Equity Affects Stock Returns.

\subsection{Debt to equity ratio and stock return}

DER is one of the solvency ratios used to reflect its ability to fulfill its obligations by using its capital to pay for it. The higher the DER, the greater the total liabilities to total equity; this shows the more significant the company's dependence on the funder or creditors. The level risk is the company getting more significant.

According to Budialim (2013), Susilowati and Turyanto (2011), and Putri (2012), suggest that DER has a positive effect on stock returns. This shows that investors in viewing DER interpret the company's responsibility to third parties, namely creditors who provide loans to companies. So that the greater the DER value, the greater the company's commitment. However, some investors view that a growing company will need debt as additional funds to meet a growing company's funding. This company requires many operational funds, which cannot be fulfilled solely from the company's capital. However, according to Kurnia (2013) and Absari \& Chandrarin (2017), DER has no positive effect on stock returns. Based on the description above, the hypothesis put forward is as follows:

H3: Debt to Equity Ratio Affects Stock Return.

\subsection{Effect of systematic risk on stock returns systematic}

the risk often referred to as market risk, is grouped into two major groups: systematic risk and unsystematic risk. Systematic risk is a risk that cannot be avoided. If this risk occurs, all types of shares will be affected. Meanwhile, unsystematic risk is a risk that only affects a particular stock or sector to be eliminated by diversifying Samsul (2006).

The capital market theory emphasizes the relationship between market risk, and the rate of return is a unidirectional and linear relationship. This means that the greater the chance that must be borne, the greater the return on the investment. This theory is supported by research from Budialim (2013), Kurnia (2013), Absari \& Chandrarin (2017), Saputra \& Leng (2002), and Pinatih \& Lestari (2017), that systematic risk has a positive effect on stock returns. Based on the description above, the hypothesis put forward is as follows:

H4: Systematic risk has a positive effect on Stock Return.

\section{Research methodology}

The approach used in this research is a quantitative approach with the type of causal associative analysis by analyzing the influence of two or more variables. The study population includes 18 sector manufacturing companies Food and Beverages listed on the Indonesia Stock Exchange for 2013-2018. The sampling technique was using the purposive sampling technique. Then selected company data based on predetermined criteria. The results obtained from the selection of samples will be used by a purposive sampling method, namely as many as eight companies suitable for use in this study. Because four companies were inconsistent in reporting their financial statements for six consecutive years, three companies suffered losses for six straight years. Three companies did not provide complete information about the variables to be measured. The total number of research samples was obtained as many as 48 research samples from 8 populations used multiplied by six years of observation. 
Table 1. Variable Operational Definition

\begin{tabular}{|c|c|c|c|c|}
\hline No & Variable & Definition & Measurement & \\
\hline 1. & Stock Returns & $\begin{array}{l}\text { The expected return of investors in } \\
\text { investing }\end{array}$ & $\boldsymbol{R}=\frac{\mathrm{P}_{i t}-\left(\mathrm{P}_{i t}-1\right)}{\mathrm{P}_{i t}-1}$ & Ratio \\
\hline 2. & $\begin{array}{l}\text { Price } \\
\text { Earnings } \\
\text { Ratio (PER) }\end{array}$ & $\begin{array}{l}\text { The value of the price per share and } \\
\text { one of the ratios used by investors } \\
\text { to show the company's earnings to } \\
\text { return funds at a certain share price } \\
\text { level. }\end{array}$ & $\begin{array}{l}\text { Price Earning Ratio }(\boldsymbol{P E R}) \\
=\frac{\text { Price Earning Stock }}{\text { Earning Stock }}\end{array}$ & Ratio \\
\hline 3. & $\begin{array}{l}\text { Return on } \\
\text { Equity } \\
\text { (ROE) }\end{array}$ & $\begin{array}{l}\text { One of the profitability ratios that } \\
\text { determines the capacity of the } \\
\text { company to produce income or } \\
\text { capital gains invested by investors }\end{array}$ & $\begin{aligned} & \text { Return On Equity }(\text { ROE }) \\
= & \frac{\text { EAT }}{\text { Shareholders }} \times 100 \%\end{aligned}$ & Ratio \\
\hline 4. & $\begin{array}{l}\text { Debt to Equity } \\
\text { Ratio (DER) }\end{array}$ & $\begin{array}{l}\text { Shareholders equity owned by the } \\
\text { company }\end{array}$ & $\begin{array}{l}\text { Debt to Equity Ratio }(\text { DER }) \\
=\frac{\text { Debt Total }}{\text { Equity Total }} \times 100 \%\end{array}$ & Ratio \\
\hline 5. & $\begin{array}{l}\text { Systematic } \\
\text { Risk }\end{array}$ & $\begin{array}{l}\text { risk is a risk that cannot be avoided; if } \\
\text { this risk occurs, then all types of } \\
\text { shares will be affected }\end{array}$ & $\boldsymbol{B}=\frac{n \sum R m R i-\sum R m \sum R i}{n \sum R m^{2}-\left(\sum R m\right)^{2}}$ & Ratio \\
\hline
\end{tabular}

Source: Previous Research, 2020

Descriptive statistics, the analytical tool used to evaluate the data obtained, as well as to test the hypotheses presented in this report, are statistics used to analyze data by explaining or describing the data collected as it is without the purpose of drawing assumptions that refer to general or generalizations. Descriptive statistics are definitions or descriptions of data seen, making it simple and understandable, from the mean, median, mode, standard deviation, maximum, and minimum values.

After knowing the descriptive statistical test results, then testing the selection of the panel data regression model is carried out. This research uses the panel data regression method. The following is a summary of the test results in determining the appropriate regression analysis model used in this study.

Table 2. Summary of Results of the Testing method

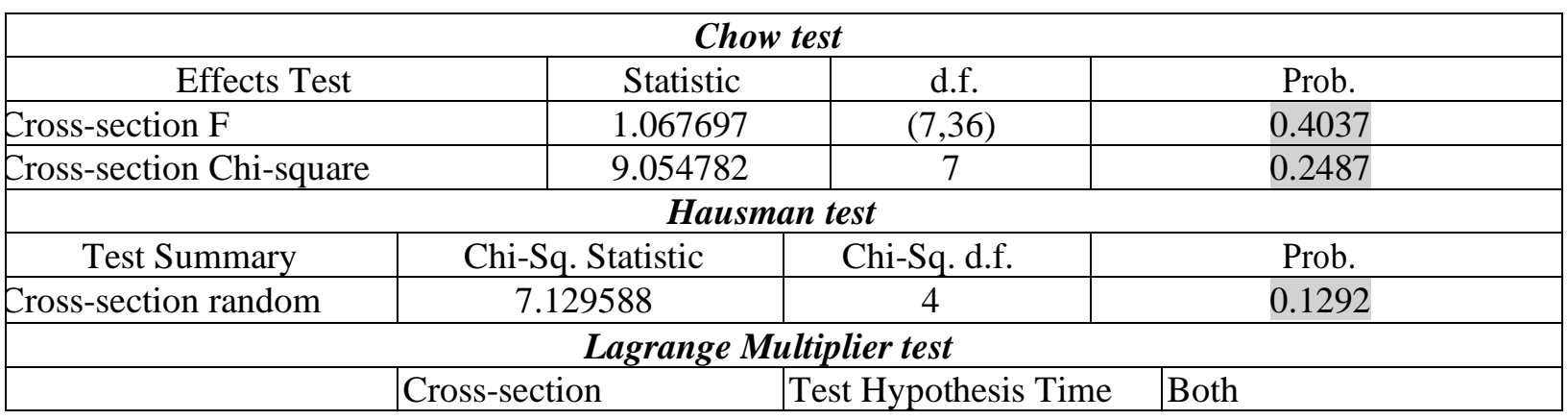




\begin{tabular}{|c|c|c|c|c|c|}
\hline \multirow[t]{2}{*}{ Breusch-Pagan } & \multicolumn{2}{|c|}{0.682815} & \multirow{2}{*}{\begin{tabular}{|l|}
3.120792 \\
$(0.0773)$
\end{tabular}} & \multicolumn{2}{|c|}{3.803607} \\
\hline & \multicolumn{2}{|c|}{$(0.4086)$} & & \multicolumn{2}{|c|}{$(0.0511)$} \\
\hline \multicolumn{6}{|c|}{ Multicolinearity test } \\
\hline & $\mathrm{R}$ & PER & $\mathrm{ROE}$ & DER & BETA \\
\hline $\mathrm{R}$ & 1.000000 & 0.011877 & 0.330452 & -0.068492 & 0.268609 \\
\hline PER & 0.011877 & 1.000000 & -0.097144 & -0.037503 & -0.146001 \\
\hline ROE & 0.330452 & -0.097144 & 1.000000 & 0.042353 & -0.189763 \\
\hline DER & -0.068492 & -0.037503 & 0.042353 & 1.000000 & 0.230398 \\
\hline BETA & 0.268609 & -0.146001 & -0.189763 & 0.230398 & 1.000000 \\
\hline \multicolumn{6}{|c|}{ Heteroskedastisitas test } \\
\hline \multicolumn{2}{|c|}{ Test } & Statistic & d.f. & \multicolumn{2}{|c|}{ Prob. } \\
\hline \multicolumn{2}{|c|}{ Breusch-Pagan LM } & 37.18971 & 28 & \multicolumn{2}{|r|}{0.1147} \\
\hline \multicolumn{6}{|c|}{ Test of the Model (Uji F) } \\
\hline F-statistic & \multirow{2}{*}{\multicolumn{2}{|c|}{$\begin{array}{l}3.828643 \\
0.009505\end{array}$}} & \multicolumn{2}{|l|}{ F-tabel } & 2,59 \\
\hline Prob(F-statistic) & & & egree of Freedom & & 0,05 \\
\hline \multicolumn{6}{|c|}{ Koefesien Determination test } \\
\hline \multicolumn{3}{|c|}{ R-squared } & & \multicolumn{2}{|r|}{0.389388} \\
\hline \multicolumn{2}{|c|}{ Adjusted R- squared } & & & & 0.202812 \\
\hline
\end{tabular}

Source: Data processed by Eviews 9.0

Based on the results of Output Eviews 9 in Table 2, it can be shown that that the results of the chow test above suggest that the probability value of Cross-section $\mathrm{F}$ and Cross-section Chi-square < alpha (0.05) is more feasible to use than the Typical Effect Model Fixed Effect Model (FEM). In addition, the Hausman test results show that it can be inferred that the probability value of random cross-section < alpha (0.05) is more feasible to use than the Random Effect Model Model (FEM) (REM). Finally, the results of the Lagrange test show that the Breusch-Pagan Cross-section probability value > alpha (0.05), the Typical Effect Model (CEM) can be assumed to be more feasible than the Random Effect Model (REM) model. Then, the next test used in this research is a test of classical assumptions. The classical assumption test is a criterion for statistical data processing that must be done in the processing of data from regression analysis if the type of data used in its estimation methodology is the Ordinary Least Type Approach Square (OLS). Ordinary Least Square (OLS)-based panel data regression models such as the Common Effect Model (CEM) and the Fixed Effect Model (FEM), There is a need for a set of classical assumption checks. However, if the regression equation used is more reliable using the Random Effect Model (REM), then the classical assumption test is not necessary since the data form of the Random Effect Model (REM) uses the General Least Squared (GLS) method in its estimation technique. It can also be seen that not all hypothesis tests are performed in panel data regression, only for panel data models based on Ordinary Least Square (OLS). The following is a description of the effects of the Multicollinearity Test and the Heteroscedasticity Test based on the results of the test in Table 2 of Evaluations 9. Multicollinearity In the regression model, it appears that no independent variables have a value greater than 0.8 , so it can be inferred that there is no multicollinearity. In addition, the heteroscedasticity test results show that the Breusch-Pagan LM value is $0.1147>0.05$, and then $\mathrm{HO}$ is acknowledged, which means that the panel data regression model does not have heteroscedasticity.

The results of the Model Feasibility Test (F Test) show that the F-value statistic 3.828643 is based on the results of Performance Eviews 9 in Table 2, while the F-table with a level of alpha $=5$ percent, df1 $(\mathrm{k}-1)=4$ and df $2(\mathrm{NK})=43$ obtained an F-table value of 2.59. Thus, it can be inferred that $\mathrm{Ha}$ is agreed with the F-value statistic 3.828643> F-table and the Prob value (F-statistic) $0.009505<0.05$. The model in this study can therefore be presumed to be sufficient for seeing the impact of exogenous variables on endogenous variables. In addition, the Value Adjusted R-squared results tend to have a value of 0.202812 ; this suggests that the price-earnings ratio, return on equity, debt to equity ratio, and systematic risk of 20.2 percent can be clarified by the action to raise the stock return, while the remainder is 79 . Other variables that are not discussed in this analysis are clarified by $8 \%$. The following is the regression equation in this study. 
$\mathrm{R}=-0.742920+0.004405 \mathrm{PER}+4.008842 \mathrm{ROE}-0.246571 \mathrm{DER}+0.446733 \mathrm{BETA}+\varepsilon_{i t}$

\section{Results and discussions}

Table 3. Descriptive Statistics

\begin{tabular}{|l|c|c|c|c|c|}
\hline & R & PER & ROE & DER & BETA \\
\hline Mean & 0.189610 & 24.30568 & 15.53894 & 80.69029 & 0.898708 \\
\hline Median & 0.059250 & 22.15500 & 15.86710 & 87.54400 & 0.957000 \\
\hline Maximum & 2.383500 & 60.77000 & 28.12160 & 150.9687 & 1.954000 \\
\hline Minimum & -0.716600 & 0.000000 & 4.359800 & 10.59310 & 0.065000 \\
\hline Std. Dev. & 0.510628 & 12.25643 & 5.414610 & 36.42589 & 0.463196 \\
\hline Observations & 48 & 48 & 48 & 48 & 48 \\
\hline
\end{tabular}

It is known that the mean or average value of the stock return (R) variable in 8 food and beverages companies is 0.189610 while the standard deviation is 0.510628 , indicating that Conservatism (R) has poor data distribution because the average (mean) value is less than the standard deviation value. Maximum stock return $(\mathrm{R})$ with a value of 2.383500 . This proves that stock return $(\mathrm{R})$ has the lowest risk level of change than other variables. This is because the products that are marketed to the market are the types of products that have been well received by the market, so this creates a stable movement in the value of stock returns from time to time.

It is known that the value means or the average amount of the variable Price Earning Ratio (PER)in 8 food and beverages companies is 24,30568. Simultaneously, the standard deviation of 12.25643 indicates that the Price Earning Ratio (PER) has fair data distribution because the mean value (mean ) is greater than the standard deviation value. Maximum on Price Earning Ratio (PER) with a value of 60.77000 . This shows that a small-Price Earning Ratio (PER) will be more attractive than a high PER. This low PER is caused by relatively high earnings per share compared to the share price so that the rate of return is better, and the payback period is even shorter.

It is known that the mean or average value of the variable Return on Equity (ROE)in 8 food and beverages companies is 15.53894 . Simultaneously, the standard deviation of 5.414610 shows that the Return on Equity (ROE) has a fair data distribution because the average value (mean) is more significant than the standard deviation value. Maximum on Return on Equity (ROE) with a value of 28,12160. This indicates that ROE is an essential indicator for the company. The better the ROE value, the more eager investors will be to invest in the company.

It is known that the mean or average value of the variable Debt to Equity Ratio (DER)in 8 food and beverages companies is 80.69029. Simultaneously, the standard deviation of 36.42589 indicates that the Debt to Equity Ratio (DER) has fair data distribution because the average value ( mean) is greater than the standard deviation value. Maximum on the Debt to Equity Ratio (DER) with a value of 150.9687 . This shows that the sample companies' total equity is available to provide collateral against the company's debt.

It is known that the mean or value - average variable Risk Systematic (BETA) in 8 companies of food and beverages 0.898708 while the standard deviation of 0.463196 is showed that the Risk of Systematic (BETA) has a distribution of data because the average value (mean) is greater than the standard deviation value. Maximum on Systematic Risk (BETA) with a value of 1.954000. This indicates that when the market price has increased or decreased, the security's stock price will rise or lower, which is greater than the market price.

Table 5. Results of Research Hypothesis Summary

\begin{tabular}{|c|c|c|c|}
\hline No & Hypothesis & Significance of & Results \\
\hline 1. & $\begin{array}{l}\mathrm{H}_{1}: \text { Price Earning Ratio has an } \\
\text { insignificant effect on Stock Returns }\end{array}$ & $\begin{array}{c}\text { t-statistic } 0.792158 \\
\text { Prob. } 0.4326\end{array}$ & Rejected \\
\hline
\end{tabular}




\begin{tabular}{|c|l|c|c|}
\hline 2. & $\begin{array}{l}\mathrm{H}_{2}: \text { Return on Equity has a significant } \\
\text { effect on Stock Return. }\end{array}$ & $\begin{array}{c}\text { t-statistic } 3.147688 \\
\text { Prob. } 0.0030\end{array}$ & Accepted \\
\hline 3. & $\begin{array}{l}\mathrm{H}_{3}: \text { Debt to Equity has an insignificant } \\
\text { effect on Stock Returns }\end{array}$ & $\begin{array}{c}\text { t-statistic }-3.129787 \\
\text { Prob. } 0.0045\end{array}$ & Rejected \\
\hline 4. & $\begin{array}{l}\mathrm{H}_{4}: \text { Systematic Risk has a significant } \\
\text { effect on Stock Returns }\end{array}$ & $\begin{array}{c}\text { t-statistic 2.906726 } \\
\text { Prob. } 0.0058\end{array}$ & Accepted \\
\hline
\end{tabular}

\section{The effect of price earning ratio on stock return}

The results of this study explain that the variable price earning ratio (PER) does not affect Stock Returns. This means that this study has not proven H1, which states that Price Earning Ratio has a positive effect on Stock Returns. Investors in food and beverage sector companies do not see price earning ratios as information that can be used to make investment decisions because the PER value is generally not much different, so it does not affect stock returns. This happens because the price per share typically has a higher value than the net income per share. Hence, investors see that dividends generated by food and beverage companies do not attract investors. This is not by the theory that the higher the PER value, the better the performance per share is to attract investors to buy these shares.

This study's results are in line with Supriantikasari \& Utami (2019) research, which found that the price-earnings ratio (PER) does not have a significant effect on stock returns. However, it is different from a study conducted by Rahyuda \& Puspitadewi (2016), which states that price-earnings ratio (PER) affects stock returns, which means that investors use price earning ratio (PER) information as a consideration in their investment decisions.

\section{Effect of return on equity on stock return}

The results of this study explain that the variable return on equity ratio (ROE) has a significant impact on Stock Return. These results imply that in food and beverages companies where shareholders generally want to know the probability level of share capital and the profits they have planted back in the form of invested profits. The ROE is increasing; the more investors are interested in investing their funds in the company so the stock price tends to increase. As an impact, stock returns also increase; thus, ROE is positively related to stock returns. A change in ROE, which is a positive signal to investors, is caught by investors. The increase in ROE shows the performance of management's ability to manage existing funds to generate profits. This is by Hutami's (2012) The rise will follow an increase in ROE in stock prices and an impact on the value of stock returns. PT proved this Indofood CBP Sukses Makmur Tbk in 2018, which experienced a high increase in ROE value, followed by the rise in the number of stock returns. This study is in line with the hypothesis that ROE has a positive stock price relationship, so that the higher the ROE, the higher the market price, since the amount of ROE means that the returns of investors will be high, so that investors will be interested in purchasing these shares and that stock market prices will increase.

This study's results are in line with research conducted by Budialim (2013) and Suherman \& Siburian (2013), who found that ROE has a positive and significant effect on stock returns. However, it is not by the research of Susilowati \& Turyanto (2011), which states that the ROE variable does not significantly affect stock returns.

\section{Effect of debt to equity on stock return}

The results of this study explain that the variable debt to equity ratio (DER) does not significantly impact stock returns. This study's results do not support the hypothesis that leverage, measured by debt to equity ratio, does not affect stock returns. A high or low level of debt to equity ratio does not significantly affect the disclosure of stock returns. This indicates that the debt to equity ratio information is less informative for investors in estimating stock returns. Based on the processed data, it can be seen that the company's debt to equity ratio tends to be high. The high debt to equity ratio indicates the extensive use of debt by the company. According to Husnan (2000), the use of debt can be justified as long as the debt is expected to provide greater economic profitability than the 
interest on the debt. So that in this case, investors focus on profit figures because total debt is more dominated by trade payables, accrued expenses, and advances for sales, where these debts are considered less dangerous and support the company to grow. This hypothesis is also not accepted because many investors tend to follow trends in the market and only want short-term profits. When the direction of changing stock prices begins to form, analysts will start to take advantage of these stock price changes for profit. They will look for the beginning of stock price changes towards the new equilibrium price and seek gain from the share price adjustment process. If the price trend shows an increase, analysts will buy shares to enjoy the benefits later when the new equilibrium price, and will sell shares if later the stock price tends to decline.

The results of this study are in line with research conducted by Rahyuda \& Puspitadewi $\underline{\text { (2016) }}$ which states that DER has a negative and insignificant effect on stock returns. However, it is not the study conducted by Suherman \& Siburian (2013) found that the DER variable has a positive and significant adverse effect on stock returns.

\section{Effect of systematic risk on return shares}

This study explains that systematic risk variables (Beta) have a significant influence on stock returns. The expected risk variable analysis results partially have a considerable influence and are positively related to stock returns. The periodic risk regression coefficient is positive, which indicates a positive relationship between stock beta and stock returns. This is because stock beta is directly proportional to individual stock returns, so that if stock beta increases, stock returns will also rise. The increasing systematic Risk of a stock will increase investors' interest in investing because they think a high risk will also give them a high return. Thus, the greater the beta, the greater the expected profit level. In other words, the more risky an investment is (as indicated by the coefficient asking), the higher the stock price will be. It can be seen in a food and beverage company that the average stock beta is below one. This indicates that the security risk is smaller than the market risk. If the market price increases or decreases, the stock price of the security will not change significantly. Meanwhile, companies with a beta above one indicate that the security risk is greater than the market risk. When the market price has increased or decreased, the security's stock price will rise or lower, which is greater than the market price.

This study supports previous research conducted by Budialim (2013), which shows that systematic Risk has a significant positive effect on stock returns and is not consistent with research conducted by $\underline{\text { Sugiarto (2011). The results of this study are not in line with the research of Rahyuda \& Puspitadewi }}$ (2016), in that their research states that leverage affects the integrity of financial statements.

\section{Conclusion}

There are four analysis results in this study, namely. First, investors in the food and beverages sector do not see the price earning ratio as information that can be used to make investment decisions because the PER value is generally not much different, so it does not affect stock returns. Second, the increasing ROE, the more investors are interested in investing their funds in the company, so that the stock price increases. As an impact, stock returns also increase; thus, ROE is positively related to stock returns. Third, the debt to equity ratio information is less informative for investors in estimating stock returns. Fourth, the riskier an investment (as indicated by the coefficient asking), the higher the stock price. It can be seen in a food and beverage company that the average stock beta is below one. This indicates that the security risk is smaller than the market risk. If the market price increases or decreases, the stock price of the security will not change significantly.

\section{Limitation and study forward}

The limitation of this research is constrained by the number of companies that do not have complete data so that many companies that should be included in the study sample must leave the example because there is no data required. The data used is only for food and beverage companies and does not include manufacturing companies as a whole. 


\section{References}

Absari, D. U. A., Sudarma, M., \& Chandrarin, G. (2012). Analisis pengaruh faktor fundamental perusahaan dan risiko sistematis terhadap return saham.

Budialim, G. (2013). Pengaruh kinerja keuangan dan risiko terhadap return saham perusahaan sektor consumer goods di Bursa Efek Indonesia Periode 2007-2011. 2(1), 1-23.

Haruman, Tendi, dkk. 2005. Pengaruh faktor fundamental dan risiko sistematis terhadap tingkat pengembalian saham BEJ. Jurnal Usahawan, 11, November, pp 26-37.

Hutami. (2012). Pengaruh Dividend Per Share (DPS), Return On Equity (ROE) dan Net Profit Margin (NPM) terhadap harga saham perusahaaan industri manufaktur yang tercatat di Bursa Efek Indonesia Periode 2006-2010.

Husnan, Suad. (2000). Manajemen keuangan teori dan penerapan (keputusan jangka panjang) Buku 1. Yogyakarta: BPFE

Kurnia, N. (2013). Pengaruh kinerja perusahaan dan risiko sistematis terhadap return saham. 2(SGEM2016 Conference Proceedings, ISBN 978-619-7105-16-2 / ISSN 1314-2704), 1-39.

Kurnia Sari, M. R. (2013). Penerapan pengendalian internal persediaan.

Meythi, dan S. Hartono. (2012). Pengaruh Informasi Laba Dan Arus Kas Terhadap Harga Saham". Jurnal Ilmiah Akuntansi FE-UKM tahun ke-3, 7, 1-17.

Murhadi, Werner R. (2013). Analisis laporan keuangan, proyeksi dan valuasi saham. Jakarta: Salemba Empat.

Pinatih, L. P. W. K., \& Lestari, P. V. (2017). Pengaruh EPS, ROE, Risiko Sistematis Terhadap Return Saham Perusahaan Otomotif Di BEI. Ekonomi Dan Bisnis, 1(2), 2990-3002.

Putri, A. A. B. (2012). Analisis Pengaruh ROA, EPS, NPM, DER Dan PBV Terhadap Return Saham. Diponegoro Business Review, 1(1), 1-11.

Rahyuda, H., \& Puspitadewi, C. I. I. (2016). Fakultas Ekonomi dan Bisnis Universitas Udayana ( Unud ), Bali , Indonesia Investasi merupakan salah satu sarana penting dalam meningkatkan kemampuan untuk mengumpulkan dan menjaga kekayaan . Investasi dapat Cokorda Istri Indah Puspitadewi , Pengaruh DER. E-Jurnal Akuntansi Universitas Udayana, 5(3), 1429-1456.

Samsul, Muhamad. (2006). Pasar modal dan manajemen portofolio. Penerbit Erlangga. Surabaya

Saputra, K. A., Elly, \& Leng, P. (2002). Pengaruh risiko sistematis dan likuiditas terhadap tingkat pengembalian saham badan-badan usaha yang go-public di Bursa Efek Jakarta pada Tahun 1999. Jurnal Manajemen Dan Kewirausahaan, 4(1), 15-25. Retrieved from http://puslit.petra.ac.id/journals/management/

Sugiarto, A. (2011). Analisa pengaruh BETA, size perusahaan, DER Dan PBV Ratio terhadap Return Saham. Jurnal Dinamika Akuntansi, 3(1), 8-14.

Suherman, \& Siburian, A. (2013). Pengaruh Earning Per Share, Debt to Equity Ratio, Return On Equity, dan Price to Book Value Terhadap Return Saham. Jurnal Riset Manajemen Sains Indonesia (JRMSI), 4(2013), 16-30.

Supriantikasari, N., \& Utami, E. S. (2019). Pengaruh return on assets, debt to equity ratio, current ratio, earning per share dan nilai tukar terhadap return saham (Studi kasus pada perusahaan go public sektor barang konsumsi yang listing di Bursa Efek Indonesia Periode 2015-2017). JRAMB, Prodi Akuntansi, Fakultas Ekonomi, UMB Yogyakarta, 5(1), 49-66

Susilowati, Y., \& Turyanto, T. (2011). Reaksi signal rasio profitabilitas dan rasio solvabilitas terhadap return saham perusahaan profitability and solvability ratio reaction signal toward stock return company. 17-37, 17-37. 